\title{
AMAR
}

AMAR (Andalas Management Review)

Vol. 2, No. 2 (2018) 11-27

The Management Institute, Faculty of Economics, Universitas Andalas ISSN (Print) 2476-9282 | ISSN (Online) 2548-155X

\section{Analisis Peningkatan Kapabilitas SDM Bidang Pengawasan Intern Pemerintah Berdasarkan Internal Audit Capability Model (IACM)}

\author{
Asniati Baharia, Galefwor Wezdy Inramus ${ }^{\mathrm{b}}$ \\ aFakultas Ekonomi, Universitas Andalas, asniati.bahari@gmail.com
}

\begin{abstract}
This research aims to identify the capabilities of the Inspectorate's human resources as well as indicators of obstacles and challenges in order to increase capabilities and the efforts that need to be done in order to increase these capabilities. In the context of conducting descriptive research with a qualitative approach, data was collected through interview techniques, document review and literature study. Interviews were conducted at the Inspectorate of Padang City. The assessment is carried out based on an analysis of the six elements of the BPKP Head Regulation Number 16 of 2015 to determine the level of the Internal Audit Capability Model (IACM). Furthermore, an analysis of obstacles and challenges is carried out as well as the steps taken to improve the capabilities of human resources at this Inspectorate. It was found that the Padang City Inspectorate was still at level 2 with notes; poor documentation of quality control forms; and limited human resources as well as limited supervision budget. Therefore, the Inspectorate of Padang City, improves the capability of the apparatus by forming capability improvement team; identify areas that need to be improved to reach level 2 fully; carry out socialization activities of audit quality control control; carry out peer review between Agency Inspectors and between APIP throughout West Sumatra; carry out assurance activities in the form of a performance audit. In addition, it also established a supervisory consultation clinic; measuring and leveraging the APIP capability improvement for compliance with level 2 and level 3 along with inputting documents and explanations on the APIP capability enhancement application that has been provided by the web-based BPKP.
\end{abstract}

Keywords: Supervisory Apparatus, APIP Capability, Internal Audit Capability Model (IACM)

\section{PENDAHULUAN}

Peraturan Pemerintah Nomor 60 tahun 2008 tentang Sistem Pengendalian Intern Pemerintah (SPIP) menyatakan bahwa untuk mencapai pengelolaan keuangan negara yang efektif, efisien, transparan dan akuntabel, pejabat Negara wajib melakukan pengendalian atas penyelenggaraan kegiatan pemerintahan dengan berpedoman pada SPIP. Dengan melakukan pengendalian berdasarkan SPIP tersebut diharapkan dapat memberikan keyakinan yang memadai sehingga tercapai efektivitas dan efisiensi penyelenggaraan pemerintahan negara, keandalan laporan keuangan, pengamanan aset negara, dan ketaatan terhadap peraturan perundang-undangan. 
Dalam melaksanakan SPIP, terdapat lima unsur yang harus dilaksanakan yaitu lingkungan pengendalian; penilaian risiko; kegiatan pengendalian; informasi komunikasi; serta pemantauan pengendalian intern. Kesemua unsur SPIP tersebut seharusnya dapat dilaksanakan secara menyeluruh, sehingga dapat menjadi bagian yang integral dalam kegiatan instansi pemerintah. Dalam pasal 47 PP No Nomor 60 tahun 2008 dinyatakan bahwa pihak yang menjalankan pengawasan intern atas penyelenggaraan tugas dan fungsi instansi pemerintah termasuk akuntabilitas keuangan negara adalah Aparat Pengawasan Intern Pemerintah (APIP).

APIP, terdiri dari Badan Pengawasan dan Keuangan Pemerintah (BPKP), Inspektorat Jenderal (Itjen), Inspektorat Provinsi dan Inspektorat Kabupaten/Kota. Dalam pelaksanaan fungsinya, APIP mengawasi pelaksanaan audit, reviu, evaluasi, pemantauan dan kegiatan pengawasan lainnya untuk memberikan keyakinan yang memadai bahwa kegiatan telah dilaksanakan secara efektif dan efesien dalam mewujudkan tata pemerintahan yang baik.

Agar dapat dikatakan efektif, di dalam Pasal 11, PP Nomor 60 tahun 2008, APIP harus dapat memberikan keyakinan yang memadai atas ketaatan, kehematan, efisiensi, dan efektivitas pencapaian tujuan penyelenggaraan tugas dan fungsi instansi; memberikan peringatan dini; dan meningkatkan efektivitas manajemen risiko untuk menyelenggarakan tugas dan fungsi instansi pemerintah serta memelihara dan meningkatkan kualitas tata kelola penyelenggaraan tugas dan fungsi instansi pemerintah.

Dalam perkembangan audit sektor publik di dunia, The Institute of Internal Auditors (IIA) yang merupakan organisasi profesi auditor intern dunia mengembangkan Internal Audit Capability Model (IACM). IACM merupakan kerangka kerja yang dapat mengidentifikasi aspek-aspek fundamental yang dibutuhkan bagi pengembangan audit intern yang efektif. IACM merupakan suatu kerangka kerja yang disiapkan oleh tim research IIA dan dipublikasikan pada tahun 2010. Kerangka kerja tersebut diadopsi oleh BPKP dalam rangka menyusun Peraturan Kepala BPKP pada tahun 2011. Pada tahun 2015 diterbitkan Peraturan Kepala BPKP Nomor 6 Tahun 2015 tentang Grand Design Peningkatan Kapabilitas Aparat Pengawasan Intern Pemerintah 2015-2019. Di samping itu, diterbitkan juga Peraturan Kepala BPKP Nomor 16 Tahun 2015 tentang Pedoman Teknis Peningkatan Kapabilitas Aparat Pengawasan Intern Pemerintah.

Di dalam IACM, ada lima tingkatan yang terdiri dari level 1 yang disebut sebagai initial, level 2 sebagai infrastructure, level 3 sebagai integrated, level 4 sebagai managed dan level 5 sebagai optimizing. Tingkatan ini dapat digunakan untuk membantu organisasi pemerintah untuk menilai kemampuan APIP dan membantu APIP untuk meningkatkan kapabilitas 
organisasi naik ke level berikutnyanya. Di samping itu, APIP juga dapat digunakan untuk memperoleh gambaran mengenai tantangan dan hambatan yang dihadapi oleh pemerintah dalam melaksanakan tata kelola yang baik dan efisien.

Untuk menentukan level IACM, Peraturan Kepala BPKP Nomor 16 Tahun 2015, mengharuskan melakukan penilaian terhadap enam elemen Key Process Area (KPA). Enam elemen KPA tersebut terdiri dari 1) Peran dan Layanan; 2) Pengelolaan Sumber Daya Manusia; 3) Praktik Profesional; 4) Akuntabilitas dan Manajemen Kinerja; 5) Budaya dan Hubungan Organisasi; dan 6) Struktur dan Tata Kelola. Dengan cara tersebut, maka akan diperoleh kesimpulan umum tentang kapabilitas APIP yang dibagi menjadi lima tingkatan atau level IACM.

Gambaran APIP berdasarkan assessment dari 2010 s.d. 2014, dari 474 APIP Pusat dan Daerah, sebanyak 404 APIP atau 85,23\% berada pada level 1 (Initial), 69 APIP atau 14,56\% berada pada level 2 (Infrastructure), dan baru 1 APIP atau 0,21\% yang berada di level 3 (Integrated) (BPKP, 2015). Sebanyak 404 APIP tingkat kapabilitasnya berada di level 1 (Initial), level ini menunjukkan masih terkandung risiko bahwa APIP belum optimal dalam memberikan nilai tambah dalam hal pengawasan intern. Rendahnya level kapabilitas APIP menandakan APIP belum mampu mencegah tindak korupsi. Banyak aparatur sipil negara yang tertangkap tangan melakukan korupsi, mulai dari kepala daerah, kepala dinas sampai dengan bendahara yang terdapat di unit terkecil sekalipun.Berdasarkan laporan dari Indonesian Corruption Watch (ICW), 2016), semenjak semester I tahun 2012 sampai dengan semester I tahun 2016 tercatat ada 448 orang pegawai negeri sipil di lingkungan pemerintah kota/kabupaten dan provinsi yang terjerat korupsi. Dengan banyaknya kasus korupsi yang tertangkap, membuat kita sadar bahwa masih lemahnya pengawasan intern yang ada pada pemerintah di Indonesia.

Pengawasan intern yang telah berjalan secara efektif dan efisien pada pemerintahan seyogyanya dapat mengurangi serta mencegah perbuatan korupsi oleh aparat pemerintah. APIP selaku pengawas yang membantu pimpinan, seharusnya dapat memiliki peranan yang strategis dan penting dalam menghindari perbuatan korupsi. APIP selalu dilibatkan dalam aktiftas keuangan Negara. Keterlibatan ini dimulai dari proses pembuatan perencanaan anggaran, pelaksanaan anggaran, dan selanjutnya pertanggungjawaban APBN/APBD. Hal ini berlanjut sampai pada pemberian rekomendasi terhadap perbaikan pada kebijakan yang telah dan akan diimplementasikan oleh pemerintah. Oleh sebab itu, diharapkan pada APIP dapat bekerja secara profesional serta peka terhadap permasalahan pemerintah dan dapat mencegah terjadinya perbuatan korupsi di semua sektor kepemerintahan (Sugihardjo, 2016). 
Tingkat kapabilitas APIP selalu dipayakan agar selalu berada pada level baik. Hal ini terbukti dengan dibuatnya oleh pemerintah Rencana Pembangunan Jangka Menengah Nasional (RPJMN) 2015-2019. Pada RPJMN 2015-2019 tersebut, Pemerintah menargetkan pada tahun 2019 kapabilitas APIP telah mencapai level 3. Hal ini dipertegas kembali pada Rapat Koordinasi Nasional Pengawasan Intern Pemerintah tanggal 13 Mei 2015 oleh Presiden Republik Indonesia bahwa kapabilitas APIP meningkat secara bertahap dan berkesinambungan (BPKP, 2015).

Inspektorat Kota Padang yang saat ini telah mencapai level 2 dengan catatan (infrastructure). Ini berarti belum semua KPA level 2 terpenuhi. Untuk itu, harus ada upaya keras untuk meningkatkan kapabilitasnya supaya meningkat dari level 2 catatan menjadi level 2 penuh, malah sebaiknya meningkat menjadi level 3 (integrated) pada tahun 2019 yang akan mendatang.

Hasil penelitian yang dilakukan oleh Heriyanto, (2016), menemukan bahwa level entitas APIP Pemerintah Kota Padang Panjang berada di level 2 (dua) IACM. Ini menyatakan bahwa Pemerintah Kota Padang Panjang dianggap telah mampu menjamin proses tata kelola sesuai dengan peraturan dan dapat mendeteksi terjadinya tindak pidana korupsi dengan baik. Di sisi lain, penelitian yang dilakukan oleh Aditantra (2017) pada Inspektorat Jenderal Kementerian Keuangan menemukan bahwa Inspektorat Jenderal telah mencapai level 3 (tiga) IACM. Ini membuktikan bahawa kapabilitas APIP Kementerian Keuangan telah mengalami peningkatan berbanding tahun sebelumnya. Hal ini terjadi karena adanya tindakan perbaikan dan usaha peningkatan level IACM oleh Kementerian Keuangan sejak awal pertama kalinya dilakukan assessment oleh BPKP pada tahun 2011.

Berdasarkan kenyataan tersebut di atas, maka perlu dilakukan studi untuk bagaimana kondisi kapabilitas APIP Inspektorat Kota Padang berdasarkan IACM. Penelitian ini bertujuan untuk mengidentifikasi kemampuan tenaga SDM Inspektorat serta identifikasi hambatan dan tantangan dalam rangka peningkatan kapabilitas dan usaha yang perlu dilakukan dalam rangka peningkatan kapabilitas tersebut. Di samping itu juga perlu diketahui bagaimana hambatan dan tantangan yang dihadapi Inspektorat Kota Padang dalam meningkatkan kapabilitas APIP. Tulisan ini memuat kerangka teoritis tentang audit internal, Aparat Pengawasan Intern Pemerintah, Peningkatan kapabilitas APIP dan Internal Audit Capability Model (IACM). Di bagian akhir tulisan ini juga dibahas bagaimana langkahlangkah yang dilakukan oleh Inspektorat Kota Padang dalam upaya peningkatan kapabilitas APIP. 


\subsection{KERANGKA TEORITIS}

\section{a. Internal}

Menurut Standar Audit Aparat Pengawasan Intern Pemerintah (APIP), definisi audit intern adalah kegiatan yang independen dan obyektif dalam bentuk pemberian keyakinan (assurance activities) dan konsultansi (consulting activities), yang dirancang untuk memberi nilai tambah dan meningkatkan operasional sebuah organisasi auditi. Kegiatan ini membantu organisasi auditi mencapai tujuannya dengan cara menggunakan pendekatan yang sistematis dan teraturuntuk menilai dan meningkatkan efektivitas dari proses manajemen risiko, kontrol (pengendalian), dan tata kelola (sektor publik).

Pengawasan intern meliputi seluruh proses kegiatan audit, reviu, evaluasi, pemantauan, dan kegiatan pengawasan lain terhadap penyelenggaraan tugas dan fungsi organisasi dalam rangka memberikan keyakinan yang memadai bahwa kegiatan telah dilaksanakan sesuai dengan tolok ukur yang telah ditetapkan secara efektif dan efisien untuk kepentingan pimpinan dalam mewujudkan tata kepemerintahan yang baik (Peraturan Pemerintah Nomor 60 Tahun 2008). Hal ini membuktikan bahwa pengendalian intern adalah sesuatu yang perlu diimplementasikan untuk mencapai pelakasanaan aktivitas pemerintah yang bersih dan berwibawa.

\section{b. Aparat Pengawasan Intern Pemerintah}

Menurut Standar Audit APIP, APIP merupakan sebuah instansi pemerintah yang dibentuk dengan tugas untuk melaksanakan pengawasan internal pada lingkungan pemerintah pusat dan/atau pemerintah daerah. Organisasi tersebut, meliputi BPKP, Inspektorat Jenderal/Inspektorat/Unit Pengawasan Intern pada Kementerian/Kementerian Negara, pada Inspektorat Utama/Inspektorat Lembaga Pemerintah Non Kementerian, pada Inspektorat/Unit Pengawasan Intern di Kesekretariatan Lembaga Tinggi Negara dan Lembaga Negara, Inspektorat Provinsi/Kabupaten/Kota, serta Unit Pengawasan Intern pada Badan HukumPemerintah lainnya sesuai dengan peraturan perundang-undangan yang berlaku.

Sejalan dengan pengertian APIP diatas terkait instansi pemerintah yang melakukan pengawasan intern, pasal 49 PP 60 Tahun 2008 menyatakan bahwa yang melaksanakan pengawasan intern pada instansi pemerintah terdiri atas: a) BPKP, b) 
Inspektorat Jenderal atau nama lain yang secara fungsional melakukan pengawasan intern, c) Inspektorat Provinsi, d) Inspektorat Kabupaten/Kota.

\section{c. Peningkatan Kapabilitas APIP}

BPKP selaku pembina APIP menyusun strategi peningkatan kapabilitas APIP dengan memperhatikan kondisi, peran, tugas dan fungsi APIP yang dituangkan dalam Peraturan Kepala BPKP Nomor 6 Tahun 2015, meliputi:

1) Penyiapan suatu perangkat kebijakan yang dapat dijadikan acuan bersama dalam upaya peningkatan kapabilitas APIP berkelas dunia.

2) Peningkatan kesadaran APIP untuk memiliki tingkat kapabilitas berkelas dunia.

3) Penilaian secara mandiri (self assessment) kapabilitas APIP sesuai kriteria intemasional dengan menggunakan 1ACM.

4) Proses penjaminan kualitas (quality assurance) oleh BPKP terhadap proses selfassessment kapabilitas APIP.

5) Peningkatan kapabilitas APIP secara mandiri (self improvement)

6) Peningkatan kompetensi SDM APIP melalul e-Learning.

\section{d. Internal Audit Capability Model (IACM)}

Internal Audit Capability Model yang selanjutnya disebut IACM, dikeluarkanoleh The Institute of Internal Auditors (IIA) pada tahun 2009. Berdasarkan Peraturan Kepala BPKP Nomor PER-1633/K/JF/2011 tentang Pedoman Teknis Peningkatan Kapabilitas APIP, IACM adalah merupakan suatu kerangka kerja yangdapat digunakan untuk mengindentifikasi aspek-aspek fundamental yang dibutuhkan untuk pengawasan intern yang efektif di sektor publik. IACM menggambarkan jalur evolusi untuk organisasi sektor publik dalam rangka mengembangkan pengawasan intern yangefektif untuk memenuhi persyaratan tata kelola organisasi dan harapan professional.

\section{e. Kerangka Penelitian}

Penelitian terkait dengan kapasitas ataupun kapabilitas aparat sudah pernah dilakukan oleh beberapa peneliti. Hasil penelitian Aditantra (2017) menemukan bahwa Inspektorat Jenderal Kementerian Keuangan telah mencapai level 3 (tiga) IACM dan telah melaksanakan langkah-langkah perbaikan untuk meningkatkan .level IACM. Selanjutnya hasil penelitian Neldy (2016) menemukan bahwa Inspektorat Kota Solok baru mencapai level 2 (dua) dengan catatan, masih terdapat langkahlangkah yang belum sesuai dengan Pedoman Teknis Peningkatan Kapabilitas. Selain itu, hasil penelitian Toding (2016) menemukan bahwa tugas dan fungsi pengawasan 
secara umum dan pengawasan terhadap pengelolaan keuangan daerah secara khusus yang dilaksanakan oleh Aparat Inspektorat Sidoarjo belum memenuhi standar kompetensi umum.

Dalam melakukan penelitian ini, metode penelitian yang dilakukan penulis mendekati metode penelitian yang dilakukan oleh Aditantra (2017). Metode penelitian dilakukan dengan mengumpulkan data melalui wawancara, reviu dokumen dan studi pustaka kepustakaan. Setelah data diperoleh, dilakukan penilaian berdasarkan tiaptiap elemen dan dianalisis hambatan dan tantangan dalam meningkatkan kapabilitas serta langkah-langkah yang dilakukan untuk meningkatkan kapabilitas. Perbedaan penelitian ini dengan penelitian Aditantra terletak pada fokus penelitian dan objek penelitian. Aditantra dalam penelitiannya lebih difokuskan pada peningkatan kapabilitas APIP untuk mencapai level 4, sedangkan penulis dalam penelitian ini lebih difokuskan pada level 2. Selain itu, objek yang diteliti oleh Aditantra yaitu Inspektorat Jenderal Kementerian Keuangan, sedangkan objek yang diteliti oleh penulis adalah Inspektorat Kota Padang.

\section{METODE}

\subsection{Jenis Penelitian}

Penelitian ini merupakan penelitian yang bersifat deskriptif dengan menggunakan pendekatan kualitatif. Pengumpulan data pada penelitian ini dilakukan dengan metode wawancara kepada praktisi atau unit yang bertanggung jawab atas peningkatan kapabilitas APIP berdasarkan IACM. Dalam hal ini wawancara dilakukan dengan pejabat maupun pegawai di Inspektorat Kota Padang.

\subsection{Fokus Penelitian}

Penelitian ini difokuskan pada pelaksanaan pekerjaan SDM pada Inspektorat di Kota Padang. Saat ini Kapabilitas APIP Inspektorat Kota Padang berdasarkan IACM berada pada level 2 (infrastructure) dengan catatan. Oleh sebab itu, maka penelitian lebih difokuskan pada kondisi kapabilitas APIP Inspektorat Kota Padang dalam mencapai level 2 (infrastructure). Selanjutnya kondisi tersebut dibandingkan dengan 10 KPA level 2 yang telah dituangkan dalam Peraturan Kepala BPKP No 16 Tahun 2015 tentang Pedoman Teknis Peningkatan Kapabilitas Aparat Pengawasan Intern Pemerintah.

\subsection{Jenis Data}


Jenis data yang digunakan dalam penelitian ini menggunakan data primer dan data sekunder. Data primer diperoleh melalui wawancara dengan pejabat maupun pegawai yang terlibat secara langsung dengan peningkatan kapabilitas APIP Inspektorat Kota Padang. Data sekunder diperoleh dari Laporan Hasil Penjaminan Kualitas (Quality Assurance) IACM Inspektorat Kota Padang. Di samping itu, data juga diperoleh berdasarkan Rencana Kerja Inspektorat Kota Padang, Piagam Audit Intern, Dokumen Pelaksanaan Anggaran dan pedoman pelaksanaan penugasan sejak perancanaan, pelaksanaan, pelaporan hasil audit, serta pemantauan tindak-lanjut dan Analisis Jabatan Inspektorat.

\subsection{Metode Pengumpulan Data}

Metode pengumpulan data dilakukan dengan wawancara serta reviu dokumen. wawancara dilakukan dengan Tim Satgas IACM Inspektorat Kota Padang guna memperoleh informasi terkait dengan peningkatan kapabilitas APIP Inspektorat Kota Padang. Wawancara dilakukan dengan mengajukan 58 pernyataan yang ada pada KPA level 2 (infrastructure) di tiap-tiap elemen dan pertanyaan yang disiapkan oleh penulis terkait hambatan, tantangan, dan langkah-langkah Inspektorat Kota Padang dalam meningkatkan kapabilitas APIP sebagai bentuk pendalaman informasi disertai juga dengan pengumpulan bukti dokumen sesuai dengan pernyataan.

Review dokumen dilakukan atas peraturan, prosedur, kebijakan maupun dokumen lainnya yang dibuat oleh Inspektorat Kota Padang. Hal ini dilakukan untuk memastikan bahwa dokumen yang diperoleh sesuai dengan kriteria Infrastruktur yang ada pada Peraturan Kepala BPKP Nomor 16 Tahun 2015 tentang Pedoman Teknis Peningkatan Kapabilitas Aparat Pengawasan Intern Pemerintah. Dokumen-dokumen yang direviu antara lain Rencana Kerja Inspektorat Kota Padang, Piagam Audit Intern, Dokumen Pelaksanaan Anggaran dan pedoman pelaksanaan penugasan sejak perancanaan, pelaksanaan, pelaporan hasil audit, dan pemantauan tindak lanjut dan Analisis Jabatan Inspektorat.

\subsection{Metode Analisis Data}

Analisis data dilakukan dengan membandingkan kondisi kapabilitas APIP Inspektorat Kota Padang saat ini dengan 58 pernyataan yang ada pada KPA level 2 tiap-tiap elemen yang telah dituangkan dalam Peraturan Kepala BPKP No 16 Tahun 2015 tentang Pedoman Teknis Peningkatan Kapabilitas Aparat Pengawasan Intern Pemerintah. Untuk mengetahui kondisi kapabilitas APIP Inspektorat Kota Padang, dilakukan penilaian dengan cara mengidentifikasi pemenuhan indikator untuk 58 pernyataan tersebut.

Penilaian kapabilitas dilakukan secara berurutan, dimulai dari pernyataan pertama sampai dengan pernyataan terakhir pada masing-masing elemen kapabilitas APIP. Setiap 
jawaban "ya" dan "sebagian" harus didukung dengan bukti dokumen maupun sistem yang sudah ada dan berjalan (dilaksanakan). Selanjutnya untuk penyimpulan tingkat kapabilitas APIP, apabila seluruh KPA setiap elemen terpenuhi semuanya, maka tingkat kapabilitas yang diperoleh adalah level tertinggi. Level tertinggi ini diperoleh karena seluruh KPA-nya terpenuhi. Akan tetapi, seandainya pemenuhan KPA setiap elemen berada pada level yang berbeda-beda atau tidak sama, maka kesimpulannya diambil berdasarkan "Level" yang elemennya paling banyak terpenuhi (modus).

Selanjutnya, setelah dilakukan penilaian terhadap kondisi kapabilitas APIP Inspektorat Kota Padang, diperoleh capaian level dari tiap-tiap elemen dan level kapabilitas APIP. Untuk elemen-elemen yang belum mencapai level 2 atau masih berada di level 1, penulis akan mengidentifikasi dan menguraikan hambatan dan tantangan yang dihadapi oleh Inspektorat Kota Padang sehingga diperoleh penjelasan penyebab elemen tersebut masih berada pada level 1. Hambatan dan tantangan tersebut penulis peroleh melalui wawancara dengan Tim Satgas Kapabilitas APIP Inspektorat Kota Padang. Setelah diperoleh hambatan dan tantangan dari proses identifikasi dan wawancara tersebut, penulis selanjutnya mengidentifikasi dan mengelompokkan hasil wawancara mengenai langkah-langkah apa saja yang akan dan/atau telah dilakukan Inspektorat Kota Padang dalam meningkatkan kapabilitas APIP.

\section{HASIL DAN PEMBAHASAN}

\subsection{Kapabilitas APIP Inspektorat Kota Padang}

Berdasarkan hasil wawancara kepada Tim Satgas IACM yang dapat dilihat pada Lampiran 1 dan hasil penilaian kapabilitas APIP yang dilakukan oleh BPKP pada tahun 2016, level kapabilitas APIP Inspektorat Kota Padang berada pada level 2 (infrastructure) dengan catatan, artinya masih ada pernyataan yang belum dipenuhi atau dipenuhi sebagian sehingga elemen tersebut berada di level 1. Elemen yang berada di level 1 tersebut yaitu elemen 3 Praktik Profesional. Kondisi kapabilitas APIP Inspektorat Kota Padang berdasarkan keenam elemen dapat dilihat sebagai berikut.

\section{a. Elemen I: Peran dan Layanan}

Pada Elemen I Peran dan Layanan, Inspektorat Kota Padang telah mencapai level 2 (infrastructure). Untuk mencapai level 2 (infrastructure) tersebut, Inspektorat Kota Padang harus memenuhi satu KPA, yaitu APIP telah memberikan jasa audit ketaatan. KPA yang pertama ini mengharuskan bahwa APIP telah melaksanakan audit kepatuhan atas area, proses, atau sistem tertentu terhadap peraturan. Peraturan ini termasuk kebijakan, rencana, prosedur, hukum, peraturan kontrak, atau kriteria lain 
yang mengatur pelaksanaan area, proses, atau sistem yang menjadi ruang lingkup audit. Untuk pemenuhan KPA pertama tersebut, Inspektorat Kota Padang harus memenuhi 9 (sembilan) pernyataan sesuai dengan pernyataan yang ada pada Peraturan Kepala BPKP Nomor 16 Tahun 2015.

Untuk pernyataan nomor 1, 7, dan 8 KPA pertama Inspektorat Kota Padang telah memiliki pedoman tentang pelaksanaan penugasan mulai dari perencanaan, pelaksanaan, pelaporan hasil audit dan pemantauan tindak lanjut. Pernyataanpernyataan tersebut dilengkapi dengan Keputusan Inspektur Kota Padang Nomor 08/INSP.SK.VIII/2014 tentang Prosedur Tetap Pelaksanaan Pemeriksaan Rutin/Kinerja, Khusus/Kasus, Monitoring dan Evaluasi Tindak Lanjut Hasil Pemeriksaan di Lingkungan Inspektorat Kota Padang. Pernyataan nomor 4, 5, 6 dan 9 terkait penyusunan rencana dan program kerjaaudit, kertas kerja audit dan laporan hasil audit serta tindak lanjut audit telah dilaksanakan Inspektorat Kota Padang dilengkapi dengan sample dokumen pemeriksaan antara lain program kerja dan laporan hasil pemeriksaan.

\section{b. Elemen II: Pengelolaan Sumber Daya Manusia}

Pada Elemen II Pengelolaan Sumber Daya Manusia, Inspektorat Kota Padang telah mencapai level 2 (infrastructure). Untuk mencapai level 2 (infrastructure) tersebut, Inspektorat Kota Padang harus memenuhi 2 KPA yaitu sebagai berikut. Pertama, APIP mengidentifikasi dan merekrut orang-orang yang kompeten. Kedua, APIP telah melakukan pengembangan profesi bagi individuauditor. Untuk pemenuhan KPA pertama tersebut, Inspektorat Kota Padang telah memenuhi lima pernyataan.

Pernyataan nomor 1 dan 2 berhubungan dengan identifikasi atas kompetensi pegawai yang dibutuhkan untuk pengawasan dan uraian jabatan pada setiap posisi jabatan di APIP. Inspektorat Kota Padang memenuhi pernyataan tersebut dengan Analisis Jabatan Inspektorat yang terdiri dari analisis jabatan struktural dan analisis jabatan fungsional. Selanjutnya pernyataan nomor 3 terkait dengan klasifikasi pemberian tunjangan untuk setiap unit jabatan di Inspektorat Kota Padang. Klasifikasi pemberian tunjangan tersebut, ditetapkan dengan Peraturan Walikota Padang Nomor 38 Tahun 2012 tentang Kriteria dan Besaran Tambahan Penghasilan Bagi Pegawai Negeri Sipil Daerah dan Pegawai Daerah/Honor di Lingkup Pemerintah Kota Padang.

Pernyataan nomor 4 terkait dengan penghitungan kebutuhan auditor dan SDM APIP beserta panduan rekrutmen telah dipenuhi Inspektorat Kota Padang dengan 
Dokumen Penghitungan Kebutuhan Jabatan Fugsional Auditor, P2UPD dan Audiwan di Lingkungan Inspektorat Pemerintah Kota Padang yang dapat dilihat pada lampiran 9 dan untuk pernyataan nomor 5 dipenuhi dengan Keputusan Inspektur Kota Padang Nomor 08/Insp.SK.VIII/ 2014.

Selanjutnya, KPA kedua, yaitu APIP telah melakukan pengembangan profesi bagi individu auditor, artinya APIP telah memastikan bahwa auditor dilingkungannya secara berkelanjutan mempertahankan dan meningkatkan kapabilitas profesional mereka. Infrastruktur minimal (namun tidak terbatas) yang harus disiapkan untuk menenuhi KPA kedua ini, Inspektorat Kota Padang telah memenuhi tujuh pernyataan. Untuk KPA kedua pernyataan nomor 6 berkaitan dengan dokumen tertulis yang memuat rencana training/pelatihan misalnya rencana pelatihan kantor sendiri (PKS). Inspektorat Kota Padang telah membuat satuan petugas PKS yang ditetapkan dengan Keputusan Inspektur Kota Padang Nomor 700.161/Inspektorat/2016 tentang Satuan Petugas Pelaksanaan Pelatihan Kantor Sendiri di Lingkungan Inspektorat Kota Padang. Selanjutnya, pernyataan nomor 7 Inspektorat Kota Padang telah mengikutsertakan pegawai untuk mengikuti kegiatan organisasi profesi misalnya AAIPI dan Surat Perintah Tugas Nomor 700.229.a/ST-V/INSP-2015 terkait dengan surat tugas untuk mengikuti workshop Akuntansi Berbasis Akrual dan Reviu LKPD berbasis Akrual tanggal 20 s.d. 21 Mei. Kemudian pernyataan nomor 8 dan 12 terkait dengan kebutuhan training dan perencanaan jumlah jam pelatihan, Inspektorat Kota Padangtelah membuat Laporan Perencanaan, Realisasi Pendidikan dan Pelatihan (Diklat). Pernyataan nomor 9, 10 dan 11 berkaitan dengan kompetensi pegawai dan sertifikasi di bidang pengawasan internal pemerintah telah dipenuhi dengan Dokumen Realisasi Pegawai yang Telah Mengikuti Diklat.

\section{c. Elemen III: Praktik Profesional}

Pada Elemen III Praktik Profesional, Inspektorat Kota Padang masih berada di level 1. Hal ini dikarenakan masih adanya pernyataan yang belum terpenuhi atau sebagian terpenuhi, yaitu pada KPA kedua di pernyataan nomor 12 dan nomor 13. Untuk memenuhi level 2 sendiri pada Elemen III Praktik Profesional terdiri dari 2 KPA yaitu:

1) Perencanaan pengawasan disusun berdasarkan pada prioritas manajemen atau pemangkukepentingan.

2) APIP memiliki kerangka kerja praktik profesional berikutprosesnya.

KPA yang pertama yaitu perencanaan pengawasan disusun berdasarkan pada prioritas manajemen atau pemangku kepentingan, artinya adanya rencana 
pengawasan secara periodik berdasarkan hasil konsultasi dengan manajemen dan pemangku kepentingan. Untuk pemenuhan KPA pertama tersebut, Inspektorat Kota Padang telah memenuhi enam pernyataan.

Pemenuhan KPA pertama Praktik Profesional lebih difokuskan pada perencanaan pengawasan dan penganggaran yang dilaksanakan oleh APIP sehingga enam pernyataan pada KPA tersebut dapat dilengkapi dengan infrastruktur yaitu Dokumen PKPT Berbasis Risiko dan SOP Pelaksanaan Kegiatan Pengawasan.

Sedangkan untuk KPA kedua yaitu kerangka kerja praktik profesional berikutprosesnya, mengharuskan Inspektorat Kota Padang memiliki kebijakan, proses, dan prosedur yang akan memandu kegiatan APIP dalam pengelolaan operasinya.

Untuk pemenuhan KPA kedua, dari tujuh pernyataan yang harus dipenuhi, Inspektorat Kota Padang telah memenuhi lima pernyataan, dua pernyataan lagi baru dipenuhi sebagian yaitu pernyataan nomor 12 dan nomor 13.

Untuk pernyataan nomor 7 dan 8 dilengkapi dengan infrastuktur berupa Piagam Audit Intern. Selanjutnya untuk pernyataan nomor 9 dilengkapi oleh Pedoman Standar Audit dan Kode Etik APIP yang dapat dilihat pada lampiran 16. Kemudian untuk pernyataan nomor 10 dan 11 dilengkapi dengan Keputusan Inspektur Kota Padang Nomor 08/INSP.SK.VIII/2014. Khusus untuk pemenuhan pernyataan nomor 12 dan 13 Inspektorat Kota Padang baru dipenuhi sebagian. Pernyataan nomor 12 terkait penerapan standar kendali mutu pada setiap penugasan audit, Inspektorat Kota Padang belum sepenuhnya melakukan standar kendali mutu tersebut. Berdasarkan hasil wawancara, hal tersebut disebabkan oleh banyaknya formulir kendali mutu yang dibuat sehingga auditor tidak melaksanakan pembuatan formulir kendali mutu dengan lengkap dan tidak mendokumentasikan standar kendali mutu tersebut dengan baik.

Selanjutnya, untuk pernyataan nomor 13 terkait penugasan pengawasan intern yang kami lakukan telah mengacu pada kebijakan, standar, pedoman dan prosedur yang ditetapkan, Inspektorat Kota Padang telah membuat pedoman telaah sejawat dengan ditetapkan melalui Keputusan Inspektur Kota Padang Nomor 800/SK-K.APIP/Tahun 2016 tentang Telaahan Sejawat Aparat Pengawasan Intern Pemerintah pada Inspektorat Kota Padang namun di tahun 2016 belum melaksanakan telaah sejawat tersebut. Berdasarkan hasil wawancara, hal tersebut disebabkan oleh keterbatasan sumber daya manusia dan anggaran. 


\section{d. Elemen IV: Akuntabilitas dan Manajemen Kinerja}

Pada Elemen IV Akuntabilitas dan Manajemen Kinerja, Inspektorat Kota Padang telah mencapai level 2 (infrastructure). Untuk mencapai level 2 (infrastructure) tersebut, Inspektorat Kota Padang harus memenuhi dua KPA yaitu:

1) Adanya perencanaan kegiatanpengawasan

2) Adanya anggaran operasional kegiatanpengawasan

KPA yang pertama yaitu adanya perencanaan kegiatan pengawasan, artinya APIP memiliki Rencana Kinerja Tahunan (RKT) penugasan pengawasan yang mencakup seluruh sumberdaya yang dibutuhkan. Infrastruktur minimal (namun tidak terbatas) Untuk pemenuhan KPA pertama tersebut, Inspektorat Kota Padang telah memenuhi tujuh pernyataan.

Selanjutnya KPA kedua yaitu adanya anggaran operasional kegiatan pengawasan, artinya APIP memperoleh pengalokasian anggaran untuk kegiatan pengawasan dan dapat mempergunakan anggaran tersebut untuk merencanakan kegiatan pengawasan. Untuk pemenuhan KPA kedua tersebut, Inspektorat Kota Padang telah memenuhi tiga pernyataan.

Untuk pernyataan nomor 1 sampai dengan 9 pada KPA pertama dan kedua berkaitan dengan rencana kinerja tahunan dan anggaran dilengkapi dengan Rencana Kerja Inspektorat Kota Padang. Selanjutnya untuk pernyataan nomor 10 berhubungan dengan reviu anggaran operasional telah dilaksanakan oleh Inspektorat Kota Padang dengan dokumen berupa Laporan Hasil Reviu atas Rencana Kerja Pemerintah Daerah (RKPD) Kota Padang.

\section{e. Elemen V: Budaya dan Hubungan Organisasi}

Pada Elemen V Budaya dan Hubungan Organisasi, Inspektorat Kota Padang telah mencapai level 2 (infrastructure). Untuk mencapai level 2 (infrastructure) tersebut, Inspektorat Kota Padang harus memenuhi satu KPA yaitu adanyapengelolaan atas bisnis proses pengawasan intern. KPA yang pertama ini mengharuskan bahwa APIP fokus pada pembinaan dan pembenahan hubungan dan infrastruktur di dalam lingkungan internalnya sendiri yang mencakup struktur organisasi, manajemen SDM, penyusunan dan pemantauan anggaran, rencana tahunan, pemenuhan perangkat dan teknologi pengawasan intern, dan pelaksanaan kegiatan pengawasan intern itu sendiri. Untuk pemenuhan KPA tersebut, Inspektorat Kota Padang harus memenuhi enam pernyataan. 
Pemenuhan pernyataan nomor 1 dan nomor 6 terkait struktur organisasi untuk melaksanakan pengawasan intern sesuai peraturan yang berlaku yang ditetapkan secara formal dalam bentuk peraturan dan telah sesuai dengan kebutuhan dan budaya organisasi telah dilengkapi dengan Peraturan Daerah Kota Padang Nomor 6 Tahun 2015 tentang Perubahan Kedua atas Peraturan Daerah Nomor 17 Tahun 2008 tentang Pembentukan Organisasi dan Tata Kerja Inspektorat, Badan Perencanaan Pembangunan Daerah, dan Lembaga Teknis Daerah. Selanjutnya, untuk pernyataan nomor 2 terkait dengan identifikasi peran dan tanggung jawab seluruh jabatan struktural, Inspektorat Kota Padang telah memiliki dengan Analisis Jabatan Inspektorat baik analisis jabatan struktural. Berikutnya untuk pernyataan nomor 5 terkait dengan analisis kebutuhan sumber daya dan perangkat pengawasan intern termasuk perangkat berbasis teknologi untuk mengelola dan melaksanakan kegiatan pengawasan intern telah dipenuhi dengan Dokumen Aplikasi Simwasda. Kemudian untuk pemenuhan pernyataan nomor 3 dan nomor 4 mengenai sarana komunikasi di lingkungan Inspektorat Kota Padang telah dipenuhi dengan kegiatan sosialisasi antara lain sosialisasi kendali mutu pemeriksaan serta penilaian SPI dan SPM.

\section{f. Elemen VI: Struktur Tata Kelola}

Pada Elemen VI Struktur Tata Kelola, Inspektorat Kota Padang telah mencapai level 2 (infrastructure). Untuk mencapai level 2 (infrastructure) tersebut, Inspektorat Kota Padang harus memenuhi dua KPA yaitu:

1) Hubungan pelaporan telahterbangun.

2) APIP memiliki akses penuh terhadap informasi, aset, dan personil unitorganisasi. KPA yang pertama, yaitu hubungan pelaporan telahterbangun, mengharuskan bahwa Inspektorat Kota Padang memiliki Rencana Kinerja Tahunan (RKT) penugasan pengawasan yang mencakup seluruh sumber daya yang dibutuhkan APIP telah membangun hubungan pelaporan (laporan kegiatan dan laporan administrasi) secara formal dilingkungannya. Untuk pemenuhan KPA pertama tersebut, Inspektorat Kota Padang telah memenuhi lima pernyataan.

Selanjutnya untuk KPA kedua yaitu APIP memiliki akses penuh terhadap informasi, aset, dan personil unitorganisasi, artinya adakewenangan bagi APIP untuk mengakses informasi, aset, dan personil organisasi K/L/Pemda, yang dibutuhkan dalam melaksanakan tugas pengawasan internnya. Untuk pemenuhan KPA kedua, Inspektorat Kota Padang telah memenuhi tiga pernyataan. 
Pemenuhan pernyataan nomor 1, 4, 5, 6, dan 7 terkait dengan intern audit charter yang telah dimiliki oleh Inspektorat Kota Padang. Selanjutnya untuk pernyataan nomor 3 dan 8 mengenai prosedur pelaporan kegiatan dan pelaporan administrasi pengawasan serta prosedur yang harus diikuti apabila auditi tidak mengungkapkan dokumen yang diperlukan untuk pengawasan telah dilengkapi oleh Inspektorat Kota Padang dengan Keputusan Inspektur Kota Padang Nomor 08/Insp.SK.VIII/2014. Untuk pernyataan nomor 2, selain dipenuhi dengan Piagam Audit Intern, dipenuhi juga dengan sosialisasi IAC.

\subsection{Hambatan dan Tantangan Inspektorat Kota Padang dalam Mencapai Level 2 IACM}

Dalam meningkatkan kapabilitas APIP, Inspektorat Kota Padang mengalami beberapa hambatan dan tantangan. Keterbatasan anggaran ini mempengaruhi kegiatan di Inspektorat Kota Padang khususnya dalam melaksankan fungsi pengawasan. Dengan adanya hambatan dan tantangan berupa formulir kendali mutu yang cukup banyak dan rumit sehingga auditor tidak melaksanakan pembuatan formulir kendali mutu dengan lengkap dan tidak mendokumentasikan standar kendali mutu tersebut mengakibatkan tidak terpenuhinya pernyataan nomor 12 pada Elemen 3 Praktik Profesional terkait penerapan standar kendali mutu pada setiap penugasan audit dengan baik.

Selanjutnya hambatan dan tantangan berupa sumber daya manusia yang terbatas pada jabatan fungsional auditor dan anggaran pengawasan yang kurang dari 1\% APBD Kota Padang mengakibatkan tidak terpenuhinya pernyataan nomor 13 pada Elemen 3 Praktik Profesional terkait penugasan pengawasan intern yang kami lakukan telah mengacu pada kebijakan, standar, pedoman dan prosedur yang ditetapkan.

\subsection{Langkah-Langkah Peningkatan Kapabilitas APIP Inspektorat Kota Padang}

Pedoman Self Assessment Peraturan Kepala BPKP No 16 Tahun 2015 terdapat lima tahapan dalam meningkatkan kapabilitas APIP. Lima tahapan peningkatan kapabilitas APIP tersebut yaitu komitmen penerapan melalui penyusunan kebijakan, kemampuan penerapan dengan penyediaan sumber daya yang memadai, pelaksanaan kegiatan sebagai implementasi dari kebijakan yang telah ditetapkan, pengukuran peningkatan kapabilitas APIP dan verifikasi untuk menilai peningkatan kapabilitias APIP.

\section{KESIMPULAN DAN IMPLIKASI}

Berdasarkan hasil penelitian dan pembahasan peningkatan kapabilitas APIP Inspektorat Kota Padang, diperoleh simpulan bahwa Kapabilitas APIP Inspektorat Kota Padang berdasarkan analisis menggunakan IACM telah mencapai level 2 (infrastructure) 
dengan catatan dengan rincian sebagai berikut: (1) Elemen I Peran dan Layanan pada level 2; (2) Elemen II Pengelolaan Sumber Daya Manusia pada level 2; (3) Elemen III Praktik Profesional pada level 1; (4) Elemen IV Akuntabilitas dan Manajemen Kinerja pada level 2; (5) Elemen V Budaya dan Hubungan Organisasi pada level 2; dan Elemen VI Struktur dan Tata Kelola pada level 2.

Sedangkan hambatan dan tantangan yang dihadapi oleh Inspektorat Kota Padang dalam meningkatkan kapabilitas APIP berupa: (1) sumber daya manusia yang terbatas pada jabatan fungsional auditor; (2) anggaran pengawasan yang kurang dari 1\% APBD Kota Padang. Hal ini mengakibatkan tidak terpenuhinya pernyataan nomor 13 pada Elemen 3 Praktik Profesional terkait penugasan pengawasan intern. Semua penelitian dilakukan telah mengacu pada kebijakan, standar, pedoman dan prosedur yang ditetapkan. Adapun langkahlangkah yang perlu dilakukan Inspektorat Kota Padang dalam meningkatkan kapabilitas APIP adalah dengan lima tahapan peningkatan kapabilitas APIP. Hal ini dilakukan melalui: (1) penyusunan kebijakan (2) peningkatan kemampuan penerapan dengan penyediaan sumber daya yang memadai; (3) pelaksanaan kegiatan sebagai implementasi dari kebijakan yang telah ditetapkan; (4) pengukuran peningkatan kapabilitas APIP; dan (5) verifikasi untuk menilai peningkatan kapabilitias APIP.

Berdasarkan kesimpulan di atas, penulis merumuskan saran dalam upaya peningkatan kapabilitas APIP Inspektorat Kota Padang dengan cara: (1) Membuat aturan/pedoman terkait penggunaan standar mutu audit pada setiap penugasan sehingga terdapat aturan/pedoman turunan dari Permenpan Nomor 19 Tahun 2009 bagi auditor dalam penggunaan standar mutu audit; (2) Melaksanakan komunikasi dengan APIP Kabupaten/Kota di Provinsi Sumatera Barat dan BPKP Perwakilan Sumatera Batar untuk menetapkan pedoman terkait telaah sejawat antar APIP Kabupaten/Kota agar memiliki keseragaman pemahaman dalam melaksanakan telaah sejawat; (3) Membuat alokasi sumber daya manusia berdasarkan analisis beban kerjaagar tugas dan fungsi Inspektorat Kota Padang dapat berjalan dengan baik; (4) Mengusulkan sistem reward kepada pemerintah melalui BPKP terkait dengan peningkatan kapabilitas APIPagar APIP lebih terpacu dalam mencapai kapabilitas yang lebih tinggi; (5) Membuat rencana tindak (action plan) secara tertulis dalam rangka mencapai level 2 penuh dan level 3; (6) Memahami dan melaksanakan Peraturan Kepala BPKP Nomor 16 Tahun 2015 tentang Pedoman Teknis Peningkatan Kapabilitas APIP dalam upaya pencapaian level 2 penuh dan level 3. 


\section{REFERENSI}

Aditrantra, J.W (2017), "Kajian Strategi Peningkatan Kapabilitas Aparat Pengawasan Intern Pemerintah Studi Kasus Inspektorat Jenderal Kementerian Keuangan", Skripsi, Sekolah Tinggi Akuntansi Negara, Tangerang Selatan.

Badan Pengawasan Keuangan dan Pembangunan (2011), Peraturan Kepala Badan Pengawasan Keuangan dan Pembangunan Nomor PER-1633/K/JF/2011 tentang Pedoman Teknis Peningkatan Kapabilitas Aparat Pengawasan Intern Pemerintah, Jakarta, BPKP.

Badan Pengawasan Keuangan dan Pembangunan (2015), Peraturan Kepala BPKP Nomor 6 Tahun 2015 tentang Grand Design Peningkatan Kapabilitas Aparat Pengawasan Intern Pemerintah 2015-2019, Jakarta, BPKP.

Badan Pengawasan Keuangan dan Pembangunan (2015), Peraturan Kepala BPKP Nomor 16 Tahun 2015 tentang Pedoman Teknis Peningkatan Kapabilitas Aparat Pengawasan Intern Pemerintah, Jakarta, BPKP.

Badan Pengawasan Keuangan dan Pembangunan (2016), "Laporan Hasil Penjaminan Kualitas (quality assurance) atas Penilaian Mandiri Kapabilitas Inspektorat Kota Padang Tahun 2016", Padang, BPKP.

Heriyanto, T.I (2016), “Analisis Kapabilitas Aparat Pengawasan Intern Pemerintah (APIP) Berdasarkan Standar IA-CM Pada Pemerintah Kota Padang Panjang", Skripsi, Universitas Andalas, Padang.

Indonesian Corruption Watch (2016)," Vonis Hakim Semakin Menguntungkan Koruptor", Jakarta, ICW.

Inspektorat Kota Padang (2015), "Penghitungan Kebutuhan Jabatan Fungsional Auditor, P2UPD dan Audiwan di Lingkungan Inspektorat Pemerintah Kota Padang", Padang, Inspektorat Kota Padang.

Inspektorat Kota Padang (2015, “Analisis Jabatan Inspektorat Kota Padang Tahun 2015”, Padang, Inspektorat Kota Padang.

Neldy, V (2016), “Analisis Peningkatan Kapabilitas APIP Dengan Menggunakan Internal Audit Capability Model (IACM), Studi Kasus Pada Inspektorat Kota Solok", Thesis, Universitas Andalas, Padang.

Toding, D.S (2016), "Kapasitas Aparat Inspektorat Dalam Pengawasan Keuangan Daerah Kabupaten Sidoarjo (Kajian terhadap Kompetensi Aparat Inspektorat di Kabupaten Sidoarjo)", Jurnal Ilmiah Administrasi Publik, Vol. 2, No. 1, Hal. 11-16. 